\title{
Modeling radiocesium bioaccumulation in a marine food chain
}

\author{
Wen-Xiong Wang ${ }^{1, *}$, Caihuan $\mathrm{Ke}^{1,2}$, K. N. Yu${ }^{2,3}$, Paul K. S. Lam ${ }^{2,4}$ \\ ${ }^{1}$ Department of Biology, Hong Kong University of Science and Technology (HKUST), Clear Water Bay, Kowloon, Hong Kong \\ ${ }^{2}$ Centre for Coastal Pollution and Conservation, and ${ }^{3}$ Department of Physics and Materials Science, and ${ }^{4}$ Department of \\ Biology and Chemistry, City University of Hong Kong, Tat Chee Avenue, Kowloon, Hong Kong
}

\begin{abstract}
We measured the transfer of radiocesium in a marine food chain from phytoplankton to bivalves and finally to a predatory gastropod (Babylonia formosae habei). The assimilation efficiency (AE) of radiocesium in both green mussels (Perna viridis) and the gastropods feeding on different diets was measured by a pulse-chase feeding radiotracer technique. The AEs of ${ }^{137} \mathrm{Cs}$ in the green mussels ranged between 0.4 and $10 \%$, and were the lowest for mussels feeding on natural sediment. The bioconcentration factor of ${ }^{137} \mathrm{Cs}$ ranged between 10 and $120 \mathrm{l} \mathrm{kg}^{-1}$ for 2 different phytoplankton species (diatom Thalassiosira pseudonana and green alga Chlorella autotrophica). The AEs of ${ }^{137} \mathrm{Cs}$ in the predatory gastropods were 44 to $58 \%$ of those feeding on mussels and clams (Ruditapes philippinarum). The efflux rate constant of ${ }^{137} \mathrm{Cs}$ in the gastropods was $0.074 \mathrm{~d}^{-1}$. Using a simple kinetic model, we showed that the majority of ${ }^{137} \mathrm{Cs}$ in the mussels was due to uptake from the dissolved phase primarily because ${ }^{137} \mathrm{Cs}$ is not particle-reactive. Uptake due to ingestion of particulate materials contributed little to the overall ${ }^{137} \mathrm{Cs}$ accumulation in the mussels, except when the resuspended sediment constituted a major food source for mussels. In contrast, dietary ingestion (trophic transfer) can be an important source for radiocesium accumulation in the predatory gastropod because of its efficient assimilation. Our modeling results indicated that the trophic transfer factor was $<1$ in both bivalves and gastropods. Consequently, ${ }^{137} \mathrm{Cs}$ was not biomagnified during its transfer to filter-feeding bivalves and predatory gastropods. This was primarily due to the high turnover rate of radiocesium in both bivalves and gastropods, even though the AE of radiocesium in the predators was high. However, the trophic transfer factor tended to increase with increasing trophic level, and a factor close to 1 may be reached when ingestion of the animals is high.
\end{abstract}

KEY WORDS: Radiocesium · Trophic transfer $\cdot$ Mussels $\cdot$ Gastropods $\cdot$ Exposure pathway

\section{INTRODUCTION}

Releases of radionuclides from nuclear facilities including power stations and fuel-reprocessing plants and the disposal of radionuclide waste have resulted in considerable concern for their chemical and biological fates in aquatic environments. The Irish and North Seas represent one of the best examples of receiving long-term input from nuclear fuel-reprocessing plants (Park et al. 1983). Among the many radionuclides dis-

*E-mail: wwang@ust.hk charged into marine environments, ${ }^{137} \mathrm{Cs}$ and ${ }^{134} \mathrm{Cs}$ are the fission products of particular interest because of their long physical half-lives and residence times in the water column, and their contrasting behavior with many other radionuclides such as transuranic nuclides. Assessment of the fate of these radionuclides in the aquatic food chain is essential for a realistic assessment of the risk of their potential impact on human health. Concern for radiocesium also arises because of its potential transfer within aquatic food webs, particularly its potential biomagnification at higher trophic levels (Rowan \& Rasmussen 1994). For example, the Cs 
concentration in piscivorous fishes was found to be greater than its concentration in planktivorous and benthivorous fishes, implying a possibility of biomagnification at the top trophic level (Forseth et al. 1991, Rowan \& Rasmussen 1994, Kasamatsu \& Ishikawa 1997). The bioconcentration factor of Cs in seabirds from Arctic regions was also higher than the bioconcentration in invertebrates and seaweeds, although there was a considerable variation of bioconcentration factors within each taxonomic group (Fisher et al. 1999). Thus, based on available evidence (Watras \& Bloom 1992), Cs and $\mathrm{Hg}$ are the only trace elements which show biomagnification at the top level of food chain. Mechanistic study of Cs biomagnification is, however, rather limited.

One critical piece of information in risk analysis is the exposure pathway of contaminants in aquatic animals (Le Fur et al. 1991, Garnier-Laplace et al. 1998). Assimilation efficiency is a critical parameter quantifying the bioavailability of a contaminant from ingested food in aquatic animals, and can be important for modeling the fate and biological transport of radiocesium in the marine food chain (Wang \& Fisher 1999a). Recent studies have extensively measured metal AEs in several marine invertebrates (Wang \& Fisher 1999a). Nonetheless, studies of the AEs of Cs are still limited, especially for marine invertebrates. Little is known about the transfer of radiocesium at different trophic levels. To our knowledge, AEs of radiocesium have only been measured for marine fishes (Hewett \& Jeffries 1978). Although some previous studies have determined the bioconcentration factor of $\mathrm{Cs}$ in several aquatic organisms (e.g. Bryan 1963, Nolan \& Dahlgaard 1991, Hutchins et al. 1996a,b, Warnau et al. 1996), the potential transfer of Cs from ingested food sources has not yet been examined. Hutchins et al. (1998) indicated that the clam Macoma balthica was not able to accumulate any Cs from ingested food sources in their soft tissues. The calculated bioconcentration factor of Cs in the clam was as low as 1, suggesting that the transfer of Cs from clams to a higher trophic level was unlikely. The bioconcentration factor however reached 34 in the common mussel Mytilus edulis within $9 \mathrm{~d}$ of exposure (Nolan \& Dahlgaard 1991). Although the bioconcentration factor of Cs in marine phytoplankton, the primarily food source for marine bivalves, is extremely low, food ingestion can be a significant source for the overall Cs uptake in marine bivalves if the uptake rate of Cs from the dissolved phase is low. Furthermore, Cs can be appreciably concentrated in marine sediment, with a typical partition coefficient in the range of 1000 to 3000 (Fisher et al. 1999). Sediment-bound Cs may be a potential source for Cs accumulation in suspension-feeding bivalves if the sediment is resuspended and ingested by bivalves. The transfer of $\mathrm{Cs}$ to the top benthic predators remains mostly unknown.

In a previous study, we showed that the bioconcentration factor of radiocesium in green mussels from subtropical and tropical waters was generally higher than for their counterparts in temperate regions (Ke et al. 2000). There is however no study on the transfer of radiocesium in the marine benthic food chain. Marine bivalves may play a critical role in the transport of radiocesium because of their high filtration activity and their control of the phytoplankton community in many coastal and estuarine waters (Bayne \& Newell 1983, Nichols 1985, Dame 1993). Although many studies have measured the radiocesium concentrations in aquatic organisms, there is no clear agreement on what factors affect the accumulation of these radionuclides (Kasamatsu \& Ishikawa 1997). In this study we determined the assimilation efficiency of radiocesium in a green mussel, Perna viridis, and a predatory gastropod, Babylonia formosae habei. The animals chosen are important commercial species in Hong Kong, and there has been great concern about their potential radiocontamination through the development and operation of nuclear power plants in Daya Bay near Hong Kong. Since the Chernobyl nuclear reactor accident, there is an increasing concern for the potential effect on human health of artificial radionuclides discharged into the environment. We used a simple model to quantify the relative importance of ingested food as a source of Cs bioaccumulation in mussels (Reinfelder et al. 1998, Wang \& Fisher 1999b).

\section{MATERIALS AND METHODS}

Under laboratory conditions, we constructed a model food chain, including Cs uptake by marine phytoplankton or sediment from the dissolved phase, followed by transfer up to green mussels (Perna viridis) or clams (Ruditapes philippinarum) and finally to the predatory gastropod (Babylonia formosae habei). The phytoplankton (diatom Thalassiosira pseudonana and green alga Chlorella autotrophica) were maintained axenically in an f/2 medium (Guillard \& Ryther 1962) under laboratory conditions. These 2 algal diets were chosen because a previous study (Chong \& Wang 2000) indicated that metals associated with the diatom were generally assimilated at the highest efficiency, whereas metals associated with the green alga were generally assimilated at the least efficiency. The green mussels were collected from Lantau Island and the clams were collected from Tolo Harbor, Hong Kong. The gastropods were purchased from fish markets in Sai Kung, and were originally collected from the eastern waters of Hong Kong. The bivalves were accli- 
mated in the laboratory for $\sim 1$ to 2 wk before the experiments, during which time they were fed with the diatom food T. pseudonana. The gastropods were maintained in the laboratory for 3 wk before the experiments, during which time they were fed with the clam or mussel soft tissue every $2 \mathrm{~d}$.

Assimilation efficiency of Cs in Perna viridis. The assimilation efficiency of radiocesium in the mussels was measured using the established method of Wang \& Fisher (1999a). Four different particles were adopted as food for the mussels: 2 phytoplankton (diatom Thalassiosira pseudonana and green alga Chlorella autotrophica), 1 detritus (dead diatom Skeletonema costatum), and natural sediment. To obtain $S$. costatum detritus, the diatoms were first grown to the stationary phase, collected by filtration, and then resuspended in natural seawater for $3 \mathrm{wk}$ (the background concentrations were $0.16 \mu \mathrm{M}$ for nitrate and $0.1 \mu \mathrm{M}$ for phosphate, measured by flow injection analysis). The natural surface oxic sediment was collected from the mudflats in Mai Po, Hong Kong, and filtered through $20 \mu \mathrm{m}$ mesh. Sediment $<20 \mu \mathrm{m}$ was used in the experiments.

The diatom Thalassiosira pseudonana and the green alga Chlorella autotrophica were radiolabeled with ${ }^{137} \mathrm{Cs}$ (as $\mathrm{CsCl}$, in $0.1 \mathrm{~N} \mathrm{HCl}$ obtained from New England Nuclear) as described in Wang \& Fisher (1996). Because phytoplankton had a very low bioconcentration factor of $\mathrm{Cs}$, a high amount of radioactivity was used (148 kBq in $50 \mathrm{ml}$ ). Both diatoms and green algae were inoculated in a full $\mathrm{f} / 2$ medium during the radiolabeling period. By the end of radiolabeling ( $4 \mathrm{~d}$, during which the cells underwent 4 to 6 divisions), the cells were collected by filtration and resuspended in $10 \mathrm{ml}$ of nonradioactive water. An aliquot of water $(0.2 \mathrm{ml})$ was sampled for total radioactivity measurements (both water and the cells) and for cell counts. The radioactivity of all cells was determined and the bioconcentration factor of Cs was calculated. After the radioactivity was measured, the cells were added to beakers containing $500 \mathrm{ml}$ of filtered seawater.

The detritus and surface sediment were radiolabeled in $10 \mathrm{ml}$ of filtered seawater containing $148 \mathrm{kBq}$ of ${ }^{137} \mathrm{Cs}$ for $3 \mathrm{~d}$. The detritus and sediment were shaken twice a day during the radiolabeling period. After the radiolabeling, the detritus and sediment were collected by filtering onto a $0.2 \mu \mathrm{m}$ membrane and resuspended into $10 \mathrm{ml}$ of filtered seawater. The radioactivity of all particles was measured before being fed to the mussels.

Individual mussels were allowed to feed on the radiolabeled particles for $<30 \mathrm{~min}$. We did not monitor the possible desorption of ${ }^{137} \mathrm{Cs}$ from the radiolabeled particles into the dissolved phase, which may be a potential source for uptake by the mussels. Following the radioactive feeding, individual mussels were rinsed with seawater, and the radioactivity of ${ }^{137} \mathrm{Cs}$ was immediately counted non-destructively for $1.5 \mathrm{~min}$, after which the mussels were placed in a 201 enclosed recirculating-seawater aquarium (Wang et al. 1995) to depurate their ingested food materials. During the $3 \mathrm{~d}$ depuration period, the radioactivity remaining in the mussels was counted at time intervals (every $3 \mathrm{~h}$ within the first day, followed by longer intervals during the following 2 to $3 \mathrm{~d}$ ). The water was changed once during the depuration period. At the end of the depuration period, the distribution of ${ }^{137} \mathrm{Cs}$ in the shells and soft tissues was determined.

Assimilation efficiency of Cs in Babylonia formosae habei. Assimilation efficiency of $\mathrm{Cs}$ in the gastropods feeding on bivalves (the green mussel Perna viridis and the clam Ruditapes philippinarum) was measured. Six individual mussels (shell length 1.5 to $2 \mathrm{~cm}$ ) were radiolabeled with ${ }^{137} \mathrm{Cs}(17.5 \mathrm{kBq}$ in 1.51 filtered seawater) for $6 \mathrm{~d}$, and 5 individual clams (shell length 1.5 to $2 \mathrm{~cm}$ ) were radiolabeled with ${ }^{137} \mathrm{Cs}$ in the dissolved phase ( $74 \mathrm{kBq}$ in $1.5 \mathrm{l}$ filtered seawater) for $2 \mathrm{~d}$. During the radiolabeling period, no food was provided to the bivalves. Dissolved uptake was the major source for radiocesium accumulation in the mussels (see 'Results'). The mussels or the clams were then removed, dissected, and the whole tissue was offered as food to the gastropods. In general, the gastropods preyed on the whole tissue immediately and ingested it within 2 to $5 \mathrm{~min}$. After feeding on the radiolabeled food, the gastropods were immediately counted for their Cs radioactivity for $1.5 \mathrm{~min}$, and placed in the enclosed recirculating seawater aquarium, as described above. During the 4 d depuration period (in nonradioactive water), the soft tissue of mussels and clams was offered as nonradioactive food to the gastropods.

Efflux rate of $\mathrm{Cs}$ in Babylonia formosae habei. To determine the efflux rate constant of radiocesium in the gastropods, they were radiolabeled with ${ }^{137} \mathrm{Cs}$ from both the dissolved phase and the food-source (mussels). Mussels were radiolabeled with ${ }^{137} \mathrm{Cs}$ for $2 \mathrm{~d}$ (17.5 kBq in $1.5 \mathrm{l}$ of filtered seawater), dissected, and offered as whole tissues to individual gastropods maintained in seawater containing ${ }^{137} \mathrm{Cs}(17.5 \mathrm{kBq}$ in $1.5 \mathrm{l}$ of filtered seawater). After $4 \mathrm{~d}$ of radiolabeling, the gastropods were removed and rinsed with nonradioactive water. They were then placed in nonradioactive water for $10 \mathrm{~min}$, allowing weakly bound ${ }^{137} \mathrm{Cs}$ to desorb from the tissue. The radioactivity of the gastropods was then measured. They were subsequently placed in an enclosed recirculating-seawater aquarium, as described above, to depurate the radiocesium for $18 \mathrm{~d}$. The water was changed every 4 to $5 \mathrm{~d}$. On Days 11 and 18, 2 individuals were dissected and the radioactivity associated with the shell, digestive gland and other soft tissue was counted. 
Modeling of Cs bioaccumulation in food chain. Cs accumulation in the mussels and gastropods can be described by the following first-order equation (Thomann 1981, Landrum et al. 1992, Wang \& Fisher 1999b):

$$
\mathrm{d} C / \mathrm{d} t=k_{\mathrm{u}} \cdot C_{\mathrm{w}}+A E \cdot I R \cdot C_{\mathrm{f}}-k_{\mathrm{e}} \cdot \mathrm{C}
$$

where $C=C$ s concentration in the mussels or gastropods at time $t\left(\mu \mathrm{g} \mathrm{g}{ }^{-1}\right.$ dry wt), $k_{\mathrm{u}}=$ Cs uptake rate constant from dissolved phase $\left(\mathrm{l} \mathrm{g}^{-1} \mathrm{~d}^{-1}\right), C_{\mathrm{w}}$ is the Cs concentration in the dissolved phase $\left(\mu \mathrm{gl}^{-1}\right), A E$ is the Cs assimilation efficiency, $I R=$ the mussel's or gastropods' ingestion rate $\left(\mathrm{g} \mathrm{g}^{-1} \mathrm{~d}^{-1}\right), C_{\mathrm{f}}=$ Cs concentration in the ingested food particles $\left(\mu \mathrm{g} \mathrm{g}^{-1}\right)$, and $k_{\mathrm{e}}=$ Cs effluxrate constant $\left(\mathrm{d}^{-1}\right)$. All weight units of tissues were in dry weight. Under steady-state conditions, Cs concentration $\left(C_{\mathrm{ss}}\right)$ can be calculated as:

$$
C_{\mathrm{ss}}=\left(k_{\mathrm{u}} \cdot C_{\mathrm{w}}+A E \cdot I R \cdot C_{\mathrm{f}}\right) / k_{\mathrm{e}}
$$

Metal physiological parameters $\left(A E, k_{\mathrm{u}}\right.$ and $k_{\mathrm{e}}$ ) were measured using kinetic approaches, and do not require assumption of steady-state condition. Thus, the relative importance of dissolved versus food uptake can be calculated as (Wang \& Fisher 1999b):

$$
R=k_{\mathrm{u}} /\left(k_{\mathrm{u}}+A E \cdot I R \cdot K d\right)
$$

where $R=$ fraction of Cs uptake from the dissolved phase and $K d=$ Cs partition coefficient or bioconcentration factor in the food particles.

The trophic transfer factor (TTF) can therefore be calculated as (Reinfelder et al. 1998, Wang \& Fisher 1999b):

$T T F=(A E \cdot I R) / k_{\mathrm{e}}$

\section{RESULTS}

\section{Cs assimilation in Perna viridis}

Bioconcentration factors (BCF) of radiocesium, calculated by the radioactivity in the cells divided by the radioactivity in the water, in the 2 phytoplankton were very low: $118 \mathrm{l} \mathrm{kg}^{-1}$ for the diatom Thalassiosira pseudonana and only $12 \mathrm{l} \mathrm{kg}^{-1}$ for the green alga Chlorella autotrophica. In our preliminary experiment, we also inoculated the diatoms and the green algae with radiocesium in artificial seawater with a low $\mathrm{K}^{+}$ concentration $(1.3 \mathrm{mM}$, compared with $7.0 \mathrm{mM}$ in natural seawater). The BCF of radiocesium was $101 \mathrm{l} \mathrm{kg}^{-1}$ for T. pseudonana and $7 \mathrm{~kg}^{-1}$ for C. autotrophica, comparable to those measured in natural seawater with a higher $\mathrm{K}^{+}$concentration. In our study, the partition coefficient of radiocesium measured in the sediment was $113 \mathrm{l} \mathrm{kg}^{-1}$. We did not measure the partitioning of radiocesium in the detritus.
Depuration of radiocesium in the mussels after feeding on 4 different types of food particles is shown in Fig. 1. In general, Cs was rapidly lost from the mussel's soft tissue within the first $2 \mathrm{~h}$. For example, $>94 \%$ of ingested Cs associated with the green algae and the sediment was egested within this period. Cs associated with the detritus was however retained somewhat more efficiently. Cs was then lost slowly from the mussels during the remaining depuration period. In a previous study, Chong \& Wang (2000) demonstrated that digestion and assimilation of metals in green mussels were completed within $48 \mathrm{~h}$ of depuration. We therefore calculated the Cs AEs as \% of Cs retained in the mussels following $48 \mathrm{~h}$ of depuration. Consequently, the AEs of radiocesium were $4.2 \pm 1.7 \%$ (mean \pm SD, $\mathrm{n}=5$ ) for Thalassiosira pseudonana, $2.8 \pm 1.1 \%$ for Chlorella autotrophica, $10.1 \pm 5.9 \%$ for detritus, and $0.4 \pm 0.1 \%$ for sediment, respectively.

\section{Cs assimilation in Babylonia formosae habei}

The depuration of ingested radiocesium in the gastropods following feeding on mussels Perna viridis and clams Ruditapes philippinarum is shown in Fig. 2. ${ }^{137} \mathrm{Cs}$ was lost rapidly from the gastropods within the first day, followed by a slower loss (i.e. a 2-phase depuration). The digestion and assimilation of $\mathrm{Cs}$ from the bivalve tissue were completed within $1 \mathrm{~d}$. We therefore used the $y$-intercept method to calculate the Cs AE, as described in Wang \& Fisher (1999a). Specifically, the \% of Cs remaining in the gastropods was modeled by the following exponential loss equation during the second compartment of depuration (24 to $96 \mathrm{~h}$ ):

$$
y=y_{0} \cdot \mathrm{e}^{-b t}
$$

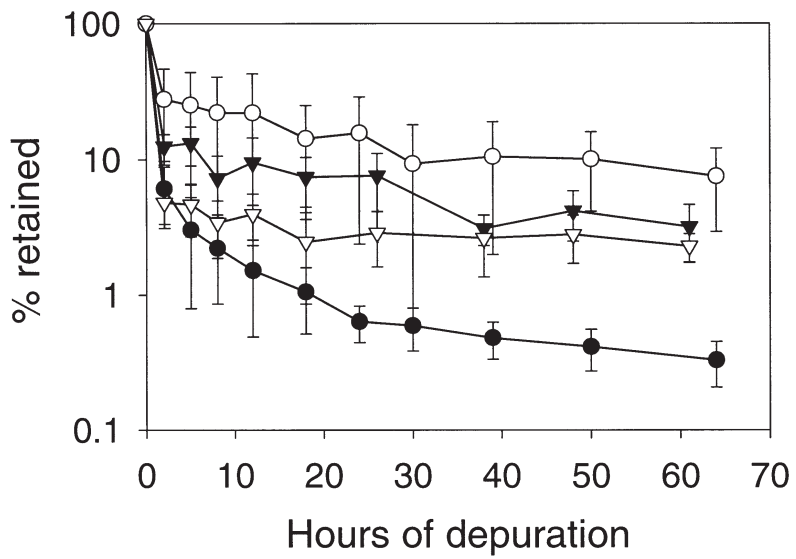

Fig. 1. Perna viridis. Depuration of radiocesium in mussels following pulse-feeding on radiolabeled food particles. (•) Sediment; (O) detritus; ( $\mathbf{v})$ diatom Thalassiosira pseudonana;

$(\nabla)$ green algae Chlorella autotrophica. Mean \pm SD $(n=5)$ 


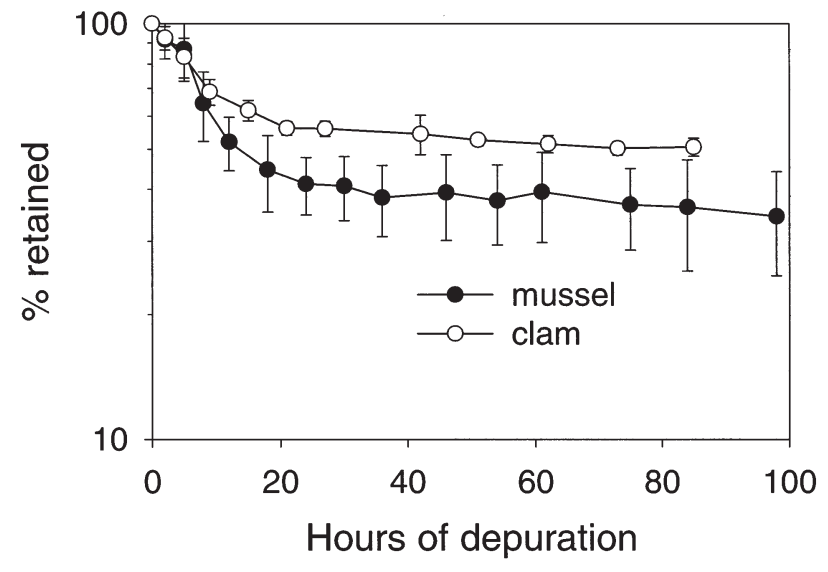

Fig. 2. Babylonia formosae habei. Depuration of radiocesium in predatory gastropods following pulse-feeding on radiolabeled bivalve food. (•) Mussel Perna viridis; (0) clam Ruditapes philippinarum. Mean $\pm \mathrm{SD}(\mathrm{n}=5)$

where $y=\%$ of Cs remaining in the gastropods, $y_{0}=$ $\mathrm{AE}$ or $y$-intercept of the linear regression between the natural $\log$ of $y$ and the time of depuration $(t)$, and $b=$ depuration-rate constant.

Thus, the AE of Cs in gastropods was calculated to be $43.6 \pm 9.7 \%$ (mean $\pm \mathrm{SD}, \mathrm{n}=5$ ) for mussels and $58.0 \pm 3.6 \%$ for clams, respectively. By the end of $4 \mathrm{~d}$ of depuration, very little Cs was found in the shell $(<0.5 \%)$. The majority of Cs $(86 \%)$ was distributed in the digestive tracts, and $14 \%$ was in the remaining soft tissues of the gastropods.

\section{Cs efflux in Babylonia formosae habei}

The retention of Cs in the gastropods following $4 \mathrm{~d}$ of exposure to radiocesium from both the dissolved phase and food sources is shown in Fig. 3. There was an initial rapid loss of Cs from the gastropod within the first day, followed by a second slower loss of Cs during the remaining depuration period ( 2 to $18 \mathrm{~d}$ ). The depuration rate constant from the first compartmental loss was $0.679 \pm 0.117 \mathrm{~d}^{-1}($ mean $\pm \mathrm{SD}, \mathrm{n}=7$ ) The efflux rate constant, calculated from the slope of the natural log of the \% of Cs retained in the gastropod and the time of depuration (2 to $18 \mathrm{~d}$ ), was $0.074 \pm$ $0.008 \mathrm{~d}^{-1}($ mean $\pm \mathrm{SD}, \mathrm{n}=7$ ). The calculated biological retention half-life was therefore $9.4 \pm 0.9 \mathrm{~d}$. The $\%$ of Cs partitioned into the second exchanging compartment was $48.0 \pm 8.4 \%$.

The distribution of Cs in the gastropods throughout the $18 \mathrm{~d}$ depuration period is shown in Fig. 4 . About 52 to $64 \%$ of the Cs was distributed in the soft tissues and 30 to $46 \%$ in the digestive tract, whereas a negligible fraction of Cs was in the shell $(<5 \%)$. The relative dis-

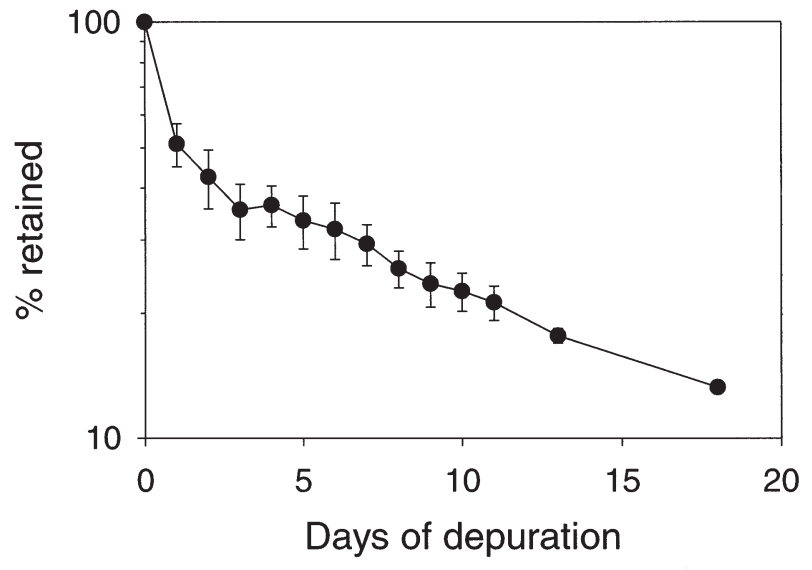

Fig. 3. Babylonia formosae habei. Depuration of radiocesium in predatory gastropods following $4 \mathrm{~d}$ feeding on radiolabeled mussels (Perna viridis) and exposure to radiocesium in dissolved phase. Mean $\pm \mathrm{SD}(\mathrm{n}=5$ to 7$)$

tribution of Cs in the gastropods was comparatively constant throughout the $18 \mathrm{~d}$ depuration period.

\section{Modeling the trophic transfer of radiocesium in mussels and gastropods}

According to Eq. (3), 4 parameters are required to model the exposure pathway of $\mathrm{Cs}$ in the green mussels, including Cs AE, mussel's IR, Cs $k_{\mathrm{u}}$ and Cs $K d$ in ingested particles. The Cs AE was taken from this study, and ranged between 0.5 and $10 \%$ for diverse particles. The uptake rate constant from the dissolved phase was $0.026 \mathrm{l} \mathrm{g}^{-1} \mathrm{~d}^{-1}$ for a mussel of $0.3 \mathrm{~g}$ tissue dry wt (Ke et al. 2000, the size used in this study). The uptake rate constant can however vary under different ecological conditions such as different temperatures

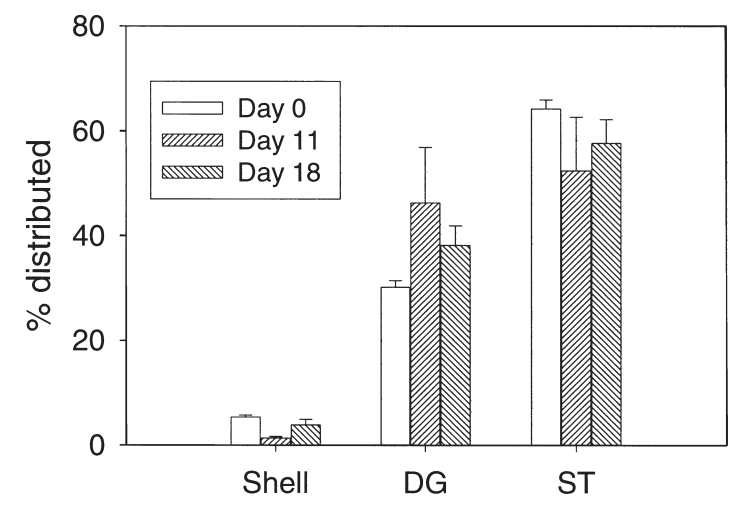

Fig. 4. Babylonia formosae habei. Distribution of radiocesium in different body parts of predatory gastropods during depuration period. DG: digestive glands; ST: other soft tissues. Mean + SD $(n=2)$ 
Table 1. Numeric values of physiological and geochemical factors used in modeling radiocesium transfer in the food chain (phytoplankton to bivalve to predatory gastropod)

\begin{tabular}{|lcll|}
\hline & Range & Mean & Source \\
\hline Mussel (Perna viridis) & & & \\
Assimilation efficiency & $0.005-0.1$ & 0.05 & This study \\
Ingestion rate $\left(\mathrm{g} \mathrm{g}^{-1} \mathrm{~d}^{-1}\right)$ & $0.1-0.3$ & 0.2 & Wong \& Cheung (1999) \\
Cs partition coefficient $\left(\mathrm{kg}^{-1}\right)$ & $10-1000$ & 100 & Fisher et al. (1999) \\
Uptake-rate constant $\left(\mathrm{l} \mathrm{g}^{-1} \mathrm{~d}^{-1}\right)$ & - & 0.026 & Ke et al. (2000) \\
Efflux-rate constant $\left(\mathrm{d}^{-1}\right)$ & - & 0.178 & Ke et al. (2000) \\
Gastropod (Babylonia formosae habei) & & \\
Assimilation efficiency & $0.4-0.8$ & 0.5 & This study \\
Ingestion rate $\left(\mathrm{g} \mathrm{g}^{-1} \mathrm{~d}^{-1}\right)$ & $0.04-0.08$ & 0.06 & Morton (1990), \\
& - & 0.074 & Ke et al. (1993) \\
Efflux-rate constant $\left(\mathrm{d}^{-1}\right)$ & - & & \\
& & & \\
\hline
\end{tabular}

a range of 10 to $1000 \mathrm{Kd}$ (or $\mathrm{BCF}$ ) in our modeling analysis. Table 1 summarizes the numeric values of each parameter used in the modeling calculation.

The relative importance of dissolved uptake versus food ingestion in the overall Cs bioaccumulation in the mussels under various conditions is shown in Fig. 5. Our modeling calculation indicated that the uptake from the dissolved phase was the dominant route for $\mathrm{Cs}$ bioaccumulation in the mussels. Partitioning of Cs in ingested particles appeared to be critical in determin- and levels of salinity. In a previous study (Ke et al. 2000), we found that the uptake rate increased by 1.6 times when the salinity was decreased from 30 to $15 \mathrm{psu}$, and by 1.4 times when the temperature was increased from 18 to $25^{\circ} \mathrm{C}$. The ingestion activity of green mussels was measured by Wong \& Cheung (1999) at different seston concentrations. The feeding rate ranged between 0.1 and $0.3 \mathrm{~g} \mathrm{~g}^{-1} \mathrm{~d}^{-1}$ (or 10 to $30 \%$ of tissue dry wt per day). The bioconcentration factor of Cs in marine phytoplankton was 10 to 120 (Thomann 1981, and this study). The partitioning coefficient of Cs in sediment was however much higher (1000 to 3000, IAEA 1985, Fisher et al. 1999). We therefore employed
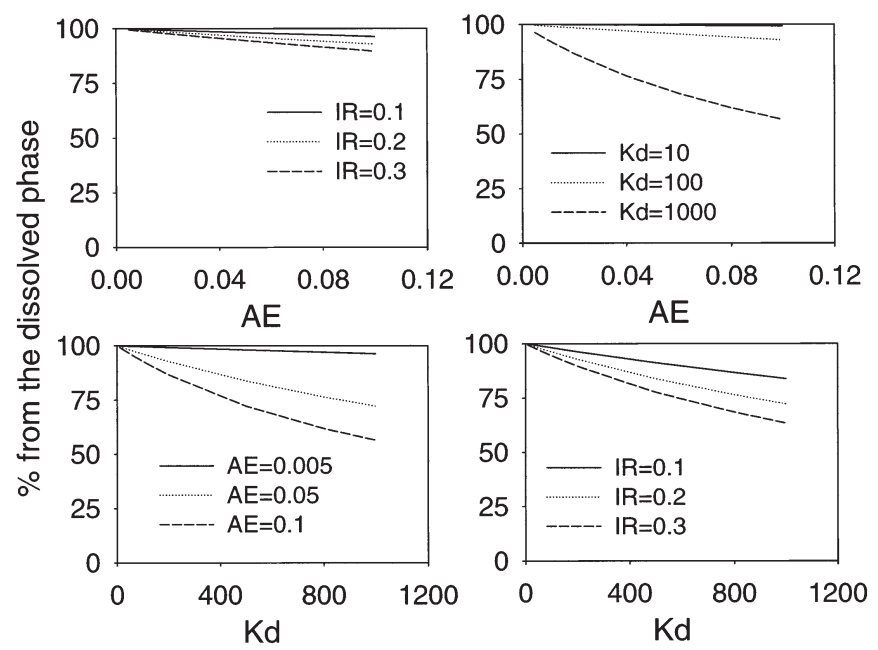

Fig. 5. Perna viridis. Model prediction of percentage of radiocesium uptake from dissolved phase as a function of $\mathrm{Cs}$ assimilation efficiency (AE) in mussels and Cs partition coefficient $(K d)$ in ingested particles $\left(\mathrm{kg}^{-1}\right)$. In modeling influences of 2 variables on relative uptake of Cs from the dissolved phase, the mean numeric value of other parameters is assumed (Table 1). IR: ingestion rate $\left(\mathrm{g} \mathrm{g}^{-1} \mathrm{~d}^{-1}\right)$ ing the significance of dietary exposure for Cs accumulation in the mussels. When the partition coefficient of Cs is 1000 (e.g. sediment), dietary exposure may potentially be an important source for Cs bioaccumulation, especially when the Cs AE is also high.

It is also possible to calculate the trophic transfer factor of Cs in both mussels and gastropods using Eq. (4). The feeding rate of the gastropods Babylonia formosae habei on diverse diets including shrimp debris and clam tissue ranged between 6 and $8 \%$ of the tissue dry weight per day (Morton 1990, Ke et al. 1993). We calculated that the trophic transfer factor of Cs in both mussels and gastropods was $<1$ under different condi-

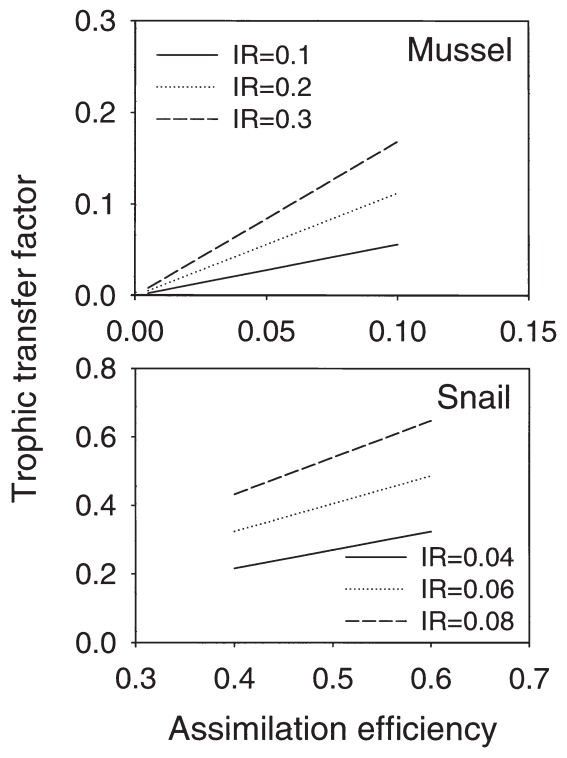

Fig. 6. Perna viridis and Babylonia formosae habei. Model prediction of trophic transfer factor of radiocesium in mussels and gastropods as a function of Cs assimilation efficiency from ingested food. IR: ingestion rate $\left(\mathrm{g} \mathrm{g}^{-1} \mathrm{~d}^{-1}\right)$ 
tions likely to be encountered by them (Fig. 6), implying that Cs was not biomagnified during its transfer to suspension-feeding bivalves and predatory gastropods. However, the transfer factor did increase with increasing trophic level from the bivalve to the gastropod.

\section{DISCUSSION}

Our measurements of the bioconcentration factor of radiocesium in the phytoplankton were similar to previous studies (range of 10 to 100; IAEA 1985, Fisher et al. 1999), indicating that little Cs was available to phytoplankton. Such a low BCF was generally considered to be due to the high competing $\mathrm{K}^{+}$concentration in the ambient seawater, although our preliminary study indicated that the bioconcentration factor determined at a much lower $\mathrm{K}^{+}$concentration did not affect radiocesium $\mathrm{BCF}$ in the algal cells. It is important to note that the BCF of Cs varied greatly among different species of phytoplankton (varying by up to 1 order of magnitude). The partition coefficient of Cs determined for sediment in our study was about 1 order of magnitude lower than the typical $K d$ in sediment measured in the field (Fisher et al. 1999), presumably because of the insufficient exchange with $\mathrm{K}^{+}$in sediment under laboratory conditions ( $3 \mathrm{~d}$ radiolabeling). With increasing exposure time, more Cs may have exchanged with $\mathrm{K}^{+}$in the sedimentary phase, resulting in a higher partition coefficient in the particles.

Our study demonstrated that little Cs was bioavailable to mussels (Perna viridis) from the ingested food source. The measured assimilation efficiency was in the range 0.4 to $10 \%$, which was at the low end of typical AEs observed for other trace metals (Wang \& Fisher 1999a). However, AE was much higher during the transfer of Cs from bivalves to gastropod (44 to $58 \%$ ). This was consistent with the finding that the assimilation of trace elements is generally higher in marine carnivores than in marine herbivores (Wang \& Fisher 1999a). For comparison, Hewett \& Jeffries (1978) found that the absorption efficiency of ${ }^{137} \mathrm{Cs}$ from food was $42 \%$ in plaice and $67 \%$ in trout. Mauro (1973) indicated that the absorption efficiencies in bluegills ranged between $3 \%$ (for detritus) and 92\% (for chironomid larvae).

Our study also suggested that there was a great variation in the Cs AE in mussels feeding on diverse food particles. Cs associated with natural sediment was least bioavailable for the mussels, whereas Cs associated with phytoplankton debris was most bioavailable. Mechanisms underlying the variability of the Cs AE in mussels are unknown. In general, it has been found that the assimilation of metals was lower from ingested sediment than from ingested phytoplankton (Gagnon \& Fisher 1997, Chong \& Wang 2000). Consistent with this, Kolehmainen (1972) indicated that bluegills (Lepornis macrochirus) had a higher assimilation efficiency of Cs from food without clay particles than from food rich in clay particles.

The depuration rate constant of Cs in the predatory gastropod was relatively rapid. However, Cs depuration appeared to vary greatly among different ecological groups of organisms (Thomann 1981), and was inversely dependent on the size of the organisms (Mauro 1973). For example, the turnover rate of radiocesium in fishes was extremely slow (Rowan \& Rasmussen 1995, Jonsson et al. 1999). Ke et al. (2000) recently found that Cs was rapidly turned over by the green mussels, with an efflux rate constant of 0.15 to $0.18 \mathrm{~d}^{-1}$. Rapid turnover of radiocesium was also found in many bivalve species (Bryan 1963, Harrison 1972, Cranmore \& Harrison 1975). Similarly, Warnau et al. (1996) reported that the depuration rate constant of radiocesium in the echinoid Paracentrotus lividus was $0.116 \mathrm{~d}^{-1}$. Among the aquatic organisms studied so far, depuration of radiocesium in gastropods may be considered intermediate between those of bivalves and fishes.

Realistic quantification of the exposure pathways of radionuclides in the mussels requires a kinetic approach (Wang \& Fisher 1999b), although it is reasonable to speculate that most radiocesium in marine herbivores may arise from the dissolved phase due to its low BCF in ingested food. Delineation of the exposure pathway of metals is dependent on the relative uptake from both the dissolved phase and the ingested food source. For example, little ${ }^{241} \mathrm{Am}$ was assimilated from ingested particles in the mussel Mytilus edulis (with an $\mathrm{AE}$ in the range of 1 to $5 \%$ : Bjerregaard et al. 1985, Wang \& Fisher 1996), which had a relatively high rate of uptake from the dissolved phase (Wang et al. 1996). However, the dietary exposure pathway was modeled as a major source for ${ }^{241} \mathrm{Am}$ bioaccumulation in the mussels, primarily because of the high partition coefficient of ${ }^{241} \mathrm{Am}$ in the ingested particles leading to a high ${ }^{241} \mathrm{Am}$ concentration in the particles and thus a high potential of influx from ingested food. Our model indicated that the importance of dissolved uptake of radiocesium was primarily due to its low reactivity in the particles. Within the typical range of $K d, \mathrm{AE}$, and IR found in nature, the relative uptake from the dissolved phase is most dependent on the $K d$ of radiocesium. Consequently, understanding the variability of radionuclide $\mathrm{Kd}$ is critical for an accurate prediction of the exposure pathway in the animals.

Our model predicted that food uptake can be an important pathway for Cs bioaccumulation in the mus- 
sels only when the $K d$ and $\mathrm{AE}$ are relatively high. However, it is important to note that the AE of radiocesium in mussels feeding on sediment was only $0.4 \%$, much lower than the AEs for other food types (e.g. phytoplankton and detritus). Using a high Cs $\mathrm{Kd}$ measured in natural sediment (3000), and an AE of $0.4 \%$ in mussels feeding on sediment, we calculated that the likely contribution of radiocesium from the sediment source would be $<13 \%$, with an ingestion rate between 10 and $30 \%$ of tissue dry weight each day. Of course, such a calculation assumes that the AE of Cs was similar to those measured in natural environments. In our study, we radiolabeled the sediment with Cs for several days, and it is conceivable that it may not have reached full equilibrium with the $\mathrm{K}^{+}$in the sediment. Garnier-Laplace et al. (1998) modeled the radiocesium exposure pathway in the freshwater zebra mussels Dreissena polymorpha. Their results suggested that the contribution from the dissolved phase was $<10 \%$ of the total Cs accumulation. In contrast, suspended materials contributed $>80 \%$ and natural phytoplankton contributed $<20 \%$ of the overall Cs accumulation in the mussels.

In our model calculation, we did not consider the variability of uptake rate constant from the dissolved phase, which could vary by 1.4 to $1.6 \times$ with a change in salinity and temperature. Ke et al. (2000) indicated that the uptake of radiocesium in green mussels was generally higher than in its counterparts (such as common mussels and clams) in other geographic regions. The BCF predicted by a kinetic model was 145, somewhat higher than the BCFs measured in bivalves from temperate or Arctic regions (Fisher et al. 1999). Marked differences in BCFs between subtropical and tropical freshwater fishes and temperate fishes have also been documented (Twining et al. 1996).

Thomann (1981) modeled the food-chain transfer factor of radiocesium in a marine planktonic food chain (phytoplankton, zooplankton, small fishes, and large fishes). He found that the increase in the bioaccumulation factor was not marked from phytoplankton to the top predator in both freshwater and marine systems, although Cs body burden at the top of the food chain was due to food transfer. However, several parameters used in the model (e.g. assimilation efficiency, excretion rate, and uptake rate of zooplankton) were estimated without realistic measurements. Recently, Fisher et al. (1999) summarized the bioconcentration factors of radiocesium in marine organisms collected from Arctic regions. There was considerable variation of Cs BCF within each major taxonomic group. However, the Cs concentration factor in the top predators such as seabirds was significantly elevated compared to that in animals at the lower levels of the food chain, implying that Cs may have been biomagnified at the top trophic level.

Trophic transfer factor is an important parameter for quantifying the biomagnification of contaminants in an aquatic system. Our modeling results did not indicate biomagnification of $\mathrm{Cs}$ along the benthic food chain. This was primarily due to the very low assimilation efficiency and the high efflux rate constant of Cs in mussels. The high efflux-rate constant of Cs was also critical for the low trophic transfer factor in gastropods. However, our study indicated that the trophic transfer factor could reach 1 at the level of the top predator if the ingestion rate of gastropods was high. With a much lower efflux rate constant in fishes and, presumably, in seabirds, it is likely that Cs may be biomagnified at these top trophic levels. Kasamatsu \& Ishikawa (1997) demonstrated that ${ }^{137} \mathrm{Cs}$ concentration increased with increasing trophic level and that the biomagnification factor $\left({ }^{137} \mathrm{Cs}\right.$ in predator $/{ }^{137} \mathrm{Cs}$ in prey) was 2.0 (1.8 to 2.2 ) in fishes. In addition, the trophic transfer factor in a freshwater mollusc (Lymnaea stagnalis) has been shown to be inversely dependent on the free calcium concentration in the water (Frantsevich et al. 1996).

Reinfelder et al. (1998) discussed the possibility of biomagnification in metal transfer at different trophic levels. It appears that many metals may be biomagnified at the lower trophic levels, while their concentrations decrease with increasing trophic levels. Our study suggested that the transport of radiocesium in the marine food chain was different from that of many metal contaminants. Trophic transfer of Cs in marine food chain may potentially lead to biomagnification at the top levels. Thus, mechanistic understanding of the trophic transfer along the marine food chain would require realistic measurements of the metal $\mathrm{AE}$, the animal's ingestion activity, and the efflux rate constant.

In summary, our study demonstrated that the assimilation efficiency of radiocesium in green mussels was generally low, but increased when the Cs was further transferred to the top gastropod predator. Similar to findings for the green mussels, the turnover of Cs in the gastropods was relatively fast. Most of the radiocesium bioaccumulation in the green mussels was predicted to derive from the dissolved phase, whereas dietary ingestion can be an important source only when the Cs partition coefficient in ingested particles is high. Ingestion of resuspended sediment may potentially be an important route for Cs bioaccumulation in the mussels because of its high Cs partition coefficient. The trophic transfer factors in both mussels and gastropods were calculated to be $<1$, but this value increased from the mussels to the gastropods. High depuration of radiocesium in both mussels and gastropods contributed to the low trophic transfer factor at both trophic levels. 
Acknowledgements. We are grateful to the anonymous reviewers for their helpful comments on this work. This study was supported by a CERG/RGC grant (HKUST6137/99M, to W.-X.W.), grant RCP 9360017 from City University of Hong Kong (to K.N.Y. and P.K.S.L.), and grant 7000661 (from City University to K.N.Y.).

\section{LITERATURE CITED}

Bayne BL, Newell RC (1983) Physiological energetics of marine molluscs. In: Saleuddin ASM, Wilbur KM (eds) The molluscs. Vol 4. Academic Press, New York, p 407-515

Bjerregaard P, Topçuolu S, Fisher NS, Fowler SW (1985) Accumulation and retention of ${ }^{237} \mathrm{Pu}$ and ${ }^{241} \mathrm{Am}$ in the mussel Mytilus edulis. Mar Ecol Prog Ser 21:99-111

Bryan GW (1963) The accumulation of radioactive caesium by marine invertebrates. J Mar Assoc UK 43:519-539

Chong K, Wang WX (2000) Assimilation of Cd, Cr, and Zn by the green mussel Perna viridis and the clam Ruditapes philippinarum. Environ Toxic Chem 19:1660-1667

Cranmore G, Harrison FL (1975) Loss of ${ }^{137} \mathrm{Cs}$ and ${ }^{60} \mathrm{Co}$ from the oyster Crassostrea gigas. Health Phys 28:319-333

Dame RF (1993) The role of bivalve filter feeder in material fluxes in estuarine ecosystems. NATO ASI Ser (V) G33: 245-269

Fisher NS, Fowler SW, Boisson F, Carroll J, Rissanen K, Salbu B, Sazykina T, Sioeblom KL (1999) Radionuclide bioconcentration factors and sediment partition coefficients in the Arctic Sea subject to contamination from dumped nuclear wastes. Environ Sci Technol 33:1979-1982

Forseth T, Ugedal O, Jonsson B, Langel A, Njastaad O (1991) Radiocaesium turnover in arcic charr (Salvelinus aplinus) and brown trout (Salmo trutta) in a Norwegian lake. J Appl Ecol 28:1053-1067

Frantsevich L, Korniushin A, Pankov I, Ermakov A, Zakharchuk T (1996) Application of molluscs for radioecological monitoring of the Chernobyl outburst. Environ Pollut 94:91-100

Gagnon C, Fisher NS (1997) The bioavailability of sedimentbound Cd, Co, and Ag to the mussel Mytilus edulis. Can J Fish Aquat Sci 54:147-156

Garnier-Laplace J, Vray F, Baudin JP, Jourd'heuil L (1998) The TRANSAQUA model applied to zebra mussels (Dreissena polymorpha) used for the biomonitoring of ${ }^{137} \mathrm{Cs}$ and ${ }^{106} \mathrm{Ru}$ contamination. Can J Fish Aquat Sci 55:999-1009

Guillard RRL, Ryther JH (1962) Studies on marine planktonic diatoms. I. Cyclotella nana Hustedt and Detonula confervacea (Cleve) Gran. Can J Microbiol 8:229-239

Harrison FL (1972) Accumulation and loss of cobalt and caesium by the marine clam, Myacaesium arenaria, under laboratory and field conditions. In: Radioactive contamination of the marine environment. IAEA, Vienna, p $453-478$

Hewett CJ, Jeffries DF (1978) The accumulation of radioactive caesium from food by the plaice (Pleuronectes platessa) and the brown trout (Salmo trutta). J Fish Biol 13:143-153

Hutchins DA, Stupakoff I, Fisher NS (1996a) Temperature effects on accumulation and retention of radionuclides in the sea star, Asterias forbesi: implications for contaminated northern waters. Mar Biol 125:701-706

Hutchins DA, Teyssie JL, Boisson F, Fowler SW, Fisher NS (1996b) Temperature effects on uptake and retention of contaminant radionuclides and trace metal by the brittle star Ophiothrix fragilis. Mar Environ Res 41:363-378

Hutchins DA, Stupakoff I, Hook S, Luoma SN, Fisher NS
(1998) Effects of arctic temperatures on distribution and retention of the nuclear waste radioclides ${ }^{241} \mathrm{Am},{ }^{57} \mathrm{Co}$, and ${ }^{137} \mathrm{Cs}$ in the bioindicator bivalve Macoma balthica. Mar Envir Res 45:17-28

IAEA (1985) Sediment Kds and concentration factors for radionuclides in the marine environment. International Atomic Energy Agency Tech Rep Ser 247:1-44

Jonsson B, Forseth T, Ugedal O (1999) Chernobyl radioactivity persists in fish. Nature 400:417-418

Kasamatsu F, Ishikawa Y (1997) Natural variation of radionuclide ${ }^{137} \mathrm{Cs}$ concentration in marine organisms with special reference to the effect of food habits and trophic level. Mar Ecol Prog Ser 160:109-120

Ke C, Fu Y, Tang H, Zhou S, Li F (1993) Studies on food diet and digestive rate of dietary protein for the ivory shell (Babylonia formorsae habei). Mar Sciences (Quingdao) 5: 5-7 (in Chinese)

Ke C, Yu KN, Lam PKS, Wang WX (2000) Uptake and depuration of cesium in the green mussel, Perna viridis. Mar Biol 137:567-575

Kolehmainen SE (1972) The balance of ${ }^{137} \mathrm{Cs}$, stable cesium and potassium of bluegill (Lepomis macrochirus Raf.) and other fish in White Oak Lake. Health Phys 23:301-315

Landrum P, Lee H, Lydy MJ (1992) Toxicokinetics in aquatic systems: model comparisons and use in hazard assessment. Environ Toxic Chem 11:1709-1725

Le Fur J, Germain P, Baron Y (1991) Modeling in situ mussel ruthenium-106 concentraiton dynamics due to fluctuating seawater radionuclide concentrations. Mar Ecol Prog Ser 75:67-78

Mauro J (1973) The accumulation of Cs-137 by Fundulus heteroclitus in the Hudson River Estuary. PhD dissertation, New York University, New York, NY

Morton B (1990) The physiology and feeding behavior of 2 marine scavenging gastropods in Hong Kong: the subtidal Babylonia lutosa (Lamarck) and the intertidal Nassarius festivus (Powys). J Mollusc Stud 56:275-288

Nichols FH (1985) Increasing benthic grazing: an alternative explanation for low phytoplankton biomass in northern San Francisco Bay during the 1976-1977 drought. Estuar Coast Shelf Sci 21:379-388

Nolan C, Dahlgaard H (1991) Accumulation of metal radiotracers by Mytilus edulis. Mar Ecol Prog Ser 70:165-174

Park PK, Kester DR, Duedall IW, Ketchum BH (1983) Radioactive waste and the ocean: an overview. In: Park PK, Kester DR, Duedall IW, Ketchum BH (eds) Wastes in the ocean. Vol 3. Radioactive wastes and the ocean. Wiley, New York, p 3-46

Reinfelder JR, Fisher NS, Luoma SN, Nichols JW, Wang WX (1998) Trace element trophic transfer in aquatic organisms: a critique of the kinetic model approach. Sci Total Environ 219:117-135

Rowan DJ, Rasmussen JB (1994) Bioaccumulation of radiocesium by fish: the influence of physicochemical factors and trophic structure. Can J Fish Aquat Sci 51:2388-2410

Rowan DJ, Rasmussen JB (1995) The elimination of radiocaesium from fish. J Appl Ecol 32:739-744

Thomann RV (1981) Equilibrium model of fate of microcontaminants in diverse aquatic food chains. Can J Fish Aquat Sci 38:280-296

Twining JR, Ferris JM, Markich SJ (1996) Bioaccumulation of ${ }^{137} \mathrm{Cs}$ and ${ }^{85} \mathrm{Sr}$ by an Australian sub-tropical freshwater teleost (Bidyanus bidyanus). Sci Total Environ 192: 245-257

Wang WX, Fisher NS (1996) Assimilation of trace elements and carbon by the mussel Mytilus edulis: effects of food composition. Limnol Oceanogr 41:197-207 
Wang WX, Fisher NS (1999a) Assimilation efficiencies of chemical contaminants in aquatic invertebrates: a synthesis. Environ Toxic Chem 18:2034-2045

Wang WX, Fisher NS (1999b) Delineating metal accumulation pathways for aquatic invertebrates. Sci Total Environ 237/238:459-472

Wang WX, Fisher NS, Luoma SN (1995) Assimilation of trace elements ingested by the mussel Mytilus edulis: effects of algal food abundance. Mar Ecol Prog Ser 129: 165-176

Wang WX, Fisher NS, Luoma SN (1996) Kinetic determina-

Editorial responsibility: Otto Kinne (Editor),

Oldendorf/Luhe, Germany tions of trace element bioaccumulation in the mussel, Mytilus edulis. Mar Ecol Prog Ser 140:91-113

Warnau M, Teyssie JL, Fowler SW (1996) Biokinetics of selected heavy metals and radionuclides in the common Mediterranean echinoid Paracentrotus lividus: sea water and food exposures. Mar Ecol Prog Ser 141:83-94

Watras C, Bloom NS (1992) Mercury and methylmercury in individual zooplankton: implications for bioaccumulation. Limnol Oceanogr 37:1313-1318

Wong WH, Cheung SG (1999) Feeding behaviour of the green mussel, Perna viridis (L.). J Exp Mar Biol Ecol 236:191-207

Submitted: January 10, 2000; Accepted: April 6, 2000

Proofs received from author(s): November 27, 2000 